\title{
Growing levels of goat biofertilizer in the initial growth of the pepper
}

Biofertilizers have been used in agroecological production with the aim of improving conditions for plant development. The objective of the research was to evaluate the effect of the application of biofertilizer on the initial development of chili peppers (Capsicum frutescens L.). The experiment was installed and conducted under field conditions from October to December 2018, in Chapadinha, city located in Maranhão. A completely randomized design was used, with 4 treatments and 5 repetitions. The experiment corresponded to the application of biofertilizer in concentrations T1: $0 \%, \mathrm{~T} 2: 20 \%, \mathrm{~T} 3: 40 \%$, T4: $60 \%$ of goat biofertilizer diluted in water. The goat biofertilizer was made using $25 \mathrm{~kg}$ of fresh goat manure, $200 \mathrm{~g}$ of ash and $500 \mathrm{~g}$ of brazilian candy called rapadura. Seedlings with eight definitive leaves were transplanted $0.8 \times 1 \mathrm{~m}$ apart. The first application of the biofertilizer was performed 15 days after transplanting and the following applications of the biofertilizer were carried out at 10-day intervals until data collection. At 60 days after transplantation, data for each variable were collected. It was observed that the variables responded well to the biofertilizer, revealing significant increases in the growth and development of the pepper plant. It is recommended 4 (four) applications of doses of goat biofertilizer with a concentration between $46 \%$ ( $460 \mathrm{ml} \mathrm{L-1)}$ to $48 \%$ (480 $\mathrm{ml} \mathrm{L-1)}$ to obtain pepper seedlings with good phytotechnical quality, because in this range the best results were found for most of the analyzed variables.

Keywords: Capsicum frutescens L.; Organic input; Dedo-de-moça; Vegetable nutrition.

\section{Níveis crescentes de biofertilizante de cabra no crescimento inicial da pimento}

\begin{abstract}
Os biofertilizantes têm sido utilizados na produção agroecológica com o objetivo de melhorar as condições de desenvolvimento das plantas. O objetivo da pesquisa foi avaliar o efeito da aplicação de biofertilizante no desenvolvimento inicial da pimenta malagueta (Capsicum frutescens L.). O experimento foi instalado e conduzido em condições de campo de outubro a dezembro de 2018, em Chapadinha, município do Maranhão. O delineamento experimental foi inteiramente casualizado, com 4 tratamentos e 5 repetições. O experimento correspondeu à aplicação de biofertilizante nas concentrações T1: 0\%, T2: 20\%, T3: 40\%, T4: 60\% de biofertilizante caprino diluído em água. O biofertilizante caprino foi feito com $25 \mathrm{~kg}$ de esterco fresco de cabra, $200 \mathrm{~g}$ de cinzas e $500 \mathrm{~g}$ de bala brasileira chamada rapadura. Mudas com oito folhas definitivas foram transplantadas com uma distância de $0,8 \times 1 \mathrm{~m}$. A primeira aplicação do biofertilizante foi realizada 15 dias após o transplante e as seguintes aplicações do biofertilizante foram realizadas em intervalos de 10 dias até a coleta de dados. Aos 60 dias após o transplante, os dados para cada variável foram coletados. Observou-se que as variáveis responderam bem ao biofertilizante, revelando aumentos significativos no crescimento e desenvolvimento da planta de pimenta. Recomenda-se 4 (quatro) aplicações de biofertilizante caprino com concentração entre $46 \%$ (460 ml L-1) a $48 \%$ (480 ml L1) para obtenção de mudas de pimenta com boa qualidade fitotécnica, pois nesta faixa o os melhores resultados foram encontrados para a maioria das variáveis analisadas.
\end{abstract}

Palavras-chave: Capsicum frutescens L.; Insumo orgânico; Dedo-de-moça; Nutrição vegetal.

\section{Topic: Agroecologia}

Reviewed anonymously in the process of blind peer.
Received: 04/03/2021

Approved: 23/03/2021
Davy Frazão Lima (iD)

Universidade Federal do Maranhão, Brasil http://lattes.cnpq.br/6484087424790205 http://orcid.org/0000-0003-1161-3497 davylima8br@gmail.com

\section{Antonio Caio de Jesus (iD)}

Universidade Federal do Maranhão, Brasil http://lattes.cnpq.br/3017273902914497 http://orcid.org/0000-0003-1746-2028 caioblastem@gmail.com

Diego de Almeida Veras (iD) Universidade Federal do Maranhão, Brasi http://lattes.cnpq.br/3472321177348257 http://orcid.org/0000-0002-1642-9376 verasdieg027@gmail.com
Ramón Yuri Ferreira Pereira (DD Universidade Federal do Maranhão, Brasil http://lattes.cnpq.br/0329684161084943 http://orcid.org/0000-0001-7600-1868 ramonyuri00@outlook.com

\section{Dário de Sousa Ramos (10)}

Universidade Federal do Maranhão, Brasi http://lattes.cnpq.br/0028712195599066 http://orcid.org/0000-0001-9202-2423 dariosousa471@gmail.com

Eduardo William de Araújo Costa (iD Universidade Federal do Maranhão, Bras http://lattes.cnpq.br/598289966939691 http://orcid.org/0000-0001-7301-206X eduardowilliam650@gmail.com

\section{Saulo Santos da Silva (iD) \\ Universidade Federal do Maranhão, Brasil http://lattes.cnpq.br/5694011259131146 http://orcid.org/0000-0003-2298-1455 santossawllo@gmail.com \\ Hermeson de Sousa Gomes (ic) \\ Universidade Federal do Maranhão, Brasil http://lattes.cnpq.br/5023672621037497 http://orcid.org/0000-0002-9620-6606 hermesongomes3@gmail.com \\ Olivan Cunha de Almeida (it) \\ Universidade Federal do Maranhão, Brasil http://lattes.cnpq.br/2467527138241747 http://orcid.org/0000-0003-4874-487X olivan.almeida.tec@gmail.com}

Luisa Julieth Parra Serrano (iD) Universidade Federal do Maranhão, Brasi http://lattes.cnpq.br/6001864868903542 http://orcid.org/0000-0002-9796-1988 julieth_ps@yahoo.com.br

\section{Referencing this:}

LIMA, D. F.; JESUS, A. C.; VERAS, D. A.; PEREIRA, R. Y. F.; RAMOS, D. S.; COSTA, E. W. A.; SILVA, S. S.; GOMES, H. S.; ALMEIDA, O. C.; SERRANO, L. J. P.. Growing levels of goat biofertilizer in the initial growth of the pepper. Revista Ibero Americana de Ciências Ambientais, v.12, n.3, p.63-71, 2021. DOI: http://doi.org/10.6008/CBPC2179$\underline{6858.2021 .003 .0006}$ 


\section{INTRODUCTION}

Peppers are classified as vegetables, from an agronomic point of view, belonging to the Solanaceae family, of the Capsicum genus. There are 5 domesticated species within the genus Capsicum: Capsicum annuum L., Capsicum chinense Jacq., Capsicum frutescens L., Capsicum baccatum L. and Capsicum pubescens, the most well-known and cultivated in Brazil being the Capsicum frutescens L. (chilli pepper) peppers and Capsicum baccatum L. (Dedo-de-moça) (FILGUEIRA, 2008). Due to the high capacity to generate jobs and income, especially for small producers, the cultivation of pepper trees plays an important role within Brazilian agriculture, due to its high socioeconomic importance (OZA et al., 2018).

Pepper agribusiness has been gaining more and more space in the market due to the great variety of products and by-products derived from this fruit, in addition to the diversity of forms of consumption. The pepper plant is one of the best examples of integration between all the links that operate in the vegetable production chain (SILVA NETO et al., 2014), helping to generate employment and income for small rural producers and their families, fixing them in the field (RÊGO et al., 2016). In addition to fresh consumption, peppers can be processed and used in various forms and product lines in the food industry. In addition, the use of peppers as an ornamental plant is growing, either in pots or in external areas (CRISPIM et al., 2018).

However, the culture of pepper is poorly studied in Brazil, especially with regard to organic fertilization (OLIVEIRA et al., 2014a). Because they are similar cultures, it is almost always suggested that the same amounts of nutrients recommended for pepper be applied to pepper (PINTO et al., 2006).

Although there are few studies that investigate the nutritional requirements of this species (RÊGO et al., 2011; CARDOSO et al., 2014), the results show that its growth and productivity are influenced by the supply of some nutrients, such as nitrogen (MEDINA-LARA et al., 2008) and phosphorus (BORGES-GÓMEZ et al., 2008). Thus, the use of organic fertilizers, such as biofertilizers, can be an important alternative for pepper nutrition (OLIVEIRA et al., 2014b).

Animal production wastes are potential organic fertilizers for agriculture, being able to totally or partially reduce the use of synthetic fertilizers, reducing production costs and maximizing productivity (SOUSA et al., 2013). Liquid organic fertilizers have a better distribution of nutrients for vegetables than other forms of organic fertilizers, which makes them easily available to plants (OLIVEIRA et al., 2014b). Among the manure from animal production, there is goat manure, which has desirable characteristics for producing organic soil fertilizers.

These facts have encouraged researchers and rural producers to experiment with biofertilizers prepared from the aerobic or anaerobic digestion of organic materials, such as foliar fertilizer to replace mineral fertilizers (SILVA et al., 2012). Its use in liquid form provides greater absorption of the necessary nutrients for plants (SOUZA et al., 2003).

In addition, biofertilizers differ from chemical fertilizers because they are produced anywhere and with different raw materials, including agricultural processing residues (OGBO, 2010). Such residues ensure results in production with a better optimization of time, and when handled properly, they help to conserve the soil (CAMARGO, 2012), also generating cost savings, since the producer does not need to buy agricultural 
inputs for the production (TRANI et al., 2013).

According to Pereira et al. (2020), the municipality of Chapadinha is located in the eastern mesoregion of the State of Maranhão and currently has approximately 80 thousand inhabitants, becoming a commercial center of fruits and vegetables of great importance in the region and in the State. Due to the need to develop new technologies and management methods that can leverage the production of chili peppers in the State of Maranhão, the objective of this study was to evaluate the effect of different concentrations of goat biofertilizer on growth and development of pepper (Capsicum frutescens L.).

\section{MATERIALS AND METHODS}

The experiment was installed and conducted in field conditions, from September to December 2017, in Chapadinha-MA, located at $03^{\circ} 44^{\prime} 30^{\prime \prime}$ south latitude and $43^{\circ} 21^{\prime} 37^{\prime \prime}$ west longitude (average altitude 107 m). The region's climate is classified as humid tropical (SELBACH et al., 2008), with total annual precipitation ranging from 1,600 to 2,000 mm (NOGUEIRA et al., 2012) and average annual temperature above $27^{\circ} \mathrm{C}$ (PASSOS et al., 2016).

A completely randomized design with four treatments and five replications was adopted, totaling 20 experimental plots. The following concentrations of goat biofertilizer (GB) were used.: T1 (control) - 0\% GB $\left(0 \mathrm{ml} \mathrm{L}^{-1}\right) ; \mathrm{T} 2-20 \% \mathrm{~GB}\left(200 \mathrm{ml} \mathrm{L}^{-1}\right) ; \mathrm{T} 3-40 \% \mathrm{~GB}\left(400 \mathrm{ml} \mathrm{L}^{-1}\right)$ and T4 - 60\% GB $\left(600 \mathrm{ml} \mathrm{L}^{-1}\right)$. The goat biofertilizer was made with $25 \mathrm{~kg}$ of fresh goat manure, $200 \mathrm{~g}$ of ash and $500 \mathrm{~g}$ of Brazilian candy called rapadura. The elements were placed and mixed in a completely sealed plastic pot, after 15 days the fermentation was completed and the goat biofertilizer was ready for use. The goat manure was obtained in the rural area of Chapadinha-MA.

The seedlings of Capsicum frutescens L. used in the present experiment were obtained by a rural producer in the municipality, who sowed them in homemade containers. Capsicum frutescens L. seedlings with eight definitive leaves were transplanted into the field at a spacing of $0.8 \times 1 \mathrm{~m}$. The first application of the goat biofertilizer was performed 15 days after transplantation (DAT) and the following applications were performed at 10-day intervals until data collection. The soil used was classified as dystrophic Yellow Latosol (LAd) (SANTOS et al., 2018).

The physical and chemical characterization of the soil used were carried out at the Soil Science Laboratory of the Federal University of Ceará, Fortaleza-CE. In the chemical characterization (Table 1), were analyzed: $\mathrm{pH}$ and the total contents of the macronutrients: phosphorus $(\mathrm{P})$, potassium $(\mathrm{K})$, calcium (Ca), magnesium (Mg) and sulfur (S) according to Brasil (2007).

Table 1: $\mathrm{pH}$ values, electrical conductivity $(\mathrm{EC})$ and total contents of nitrogen $(\mathrm{N})$, phosphorus (P), potassium (K), calcium (Ca), magnesium (Mg) and sulfur (S) of the Dystrophic Yellow Latosol (LAd).

\begin{tabular}{|c|c|c|c|c|c|c|c|c|}
\hline & $\mathrm{pH}$ & $\begin{array}{l}\text { EC } \\
d S m^{-1}\end{array}$ & $\begin{array}{l}\mathrm{N} \\
\mathrm{g} \mathrm{Kg}^{-1}\end{array}$ & $\begin{array}{l}\mathrm{P} \\
\mathrm{mg} \mathrm{Kg}^{-1}\end{array}$ & K & $\begin{array}{c}\mathrm{Ca} \\
\mathrm{cmol}_{\mathrm{C}} \mathrm{Kg}^{-1}=\end{array}$ & $\mathrm{Mg}$ & $S$ \\
\hline LAd & 5.06 & 0.10 & 0.63 & 13 & 0.07 & 0.80 & 0.30 & 1.5 \\
\hline
\end{tabular}

In the granulometric analysis of the soil, it was found that the LAd has: $384 \mathrm{~g}$ coarse sand kg ${ }^{-1} ; 336 \mathrm{~g}$ $\mathrm{kg}^{-1}$ fine sand; $112 \mathrm{~g}$ of silt $\mathrm{kg}^{-1} ; 168 \mathrm{~g}$ of total clay $\mathrm{kg}^{-1} ; 38 \mathrm{~g}$ of natural clay $\mathrm{kg}^{-1}$; crumbling sandy soil 
classification; and $0.77 \mathrm{~g} \mathrm{~g}^{-1}$ flocculation degree. For physical characterization (Table 2), the following were analyzed: global density (GD), particle density (PD) and porosity (\%), determined according to procedures described by Schmitz et al. (2002).

Table 2: Global density (GD), particle density (PD) and porosity of Dystrophic Yellow Latosol (LAd).

\begin{tabular}{llll} 
& $\mathrm{GD}$ & $\mathrm{PD}$ & Porosity (\%) \\
\cline { 2 - 3 } & $\mathrm{g} \mathrm{cm}^{-3}$ & & 45,99 \\
\hline $\mathrm{LAd}$ & 1,44 & 2,67 & \\
\hline
\end{tabular}

At 60 DAT, the aerial part and the root system were collected, weighed and subsequently dried in an oven with air circulation to measure the effect of the biofertilizer on the initial growth of the pepper plant.

The following parameters were evaluated: I) shoot height $(\mathrm{cm})$ : measured with the aid of a ruler graduated in $\mathrm{mm}$; II) stem diameter $(\mathrm{mm})$ : obtained with the aid of a digital caliper (Digimess ${ }^{\circledR}$ ); III) root length $(\mathrm{cm})$ : obtained with a ruler graduated in $\mathrm{mm}$; IV) number of branches (per plant): obtained by manually counting branches in each plant; V) shoot dry mass (g): obtained by drying in an oven with forced air circulation at a temperature of $65^{\circ} \mathrm{C}$ for 72 hours and weighed on a scale with an accuracy of $0.01 \mathrm{~g}$; VI) root dry mass (g): measured in the same way as the dry mass of the aerial part; VII) total dry mass (g): obtained by adding the dry mass of the aerial part to the dry root mass; VIII) shoot height / stem diameter ratio: obtained through the ratio between the height of the plant and the diameter of the stem; IX) shoot height / root length ratio: obtained by the ratio of the shoot height and the root length; $X$ ) shoot dry mass / root dry mass ratio: obtained through the ratio between the two variables; $\mathrm{XI}$ ) shoot height / shoot dry mass ratio: obtained by the shoot height / shoot dry mass ratio; XII) root specific growth: measured by the ratio of root length to root dry mass; XIII) root thickness: obtained by the ratio between root dry mass and root length; XIV) Dickson's quality index: obtained through the formula developed by Dickson et al. (1960):

$$
\mathrm{DQI}=\frac{\mathrm{TDM}}{\frac{\mathrm{SH}}{\mathrm{SD}}+\frac{\mathrm{SDM}}{\mathrm{RDM}}}
$$

The data obtained were submitted to analysis of variance (ANOVA) by the $F$ test at the level of $5 \%$ significance for diagnosis of significant effect using the software Infostat ${ }^{\circledR}$ version 2015 I (DI RIENZO et al., 2015). In cases of significant differences between treatments, data were explored through polynomial regression analysis, the equations being selected by the $F$ test, when the level of significance was $\alpha=0.05$ of probability.

\section{RESULTS AND DISCUSSION}

Through the analysis of variance, it was observed that the variables plant height, stem diameter, dry mass of the aerial part and total dry mass had a significant effect $(p<0.05)$ with the use of goat biofertilizer 
(GB). The other variables did not obtain significance $(p>0.05)$ with the use of the compound (Table 3$)$.

Table 3: Analysis of variance of the variables shoot height (SH), stem diameter (SD), root length (RL), number of branches (NB), shoot dry mass (SDM), root dry mass (RDM), total dry mass (TDM), shoot height / stem diameter ratio (SH/SD), shoot height / root length ratio (SH/RL), shoot dry mass / root dry mass ratio (SDM/RDM), shoot height / shoot dry mass ratio (SH/SDM), root specific growth (RSG), root thickness (RT) and Dickson's quality index (DQI) of pepper trees (Capsicum frutescens L.) due to different concentrations of goat biofertilizer.

\begin{tabular}{|c|c|c|c|c|c|c|c|c|}
\hline \multirow{2}{*}{ SV } & \multirow[t]{2}{*}{ DF } & \multicolumn{3}{|c|}{ Medium square } & & & & \\
\hline & & SH & SD & $\mathrm{RL}$ & NB & SDM & RDM & TDM \\
\hline Treatment & 3 & $576.75^{*}$ & $10.87^{*}$ & $4586.48^{\text {ns }}$ & $15.25^{\text {ns }}$ & 181.99* & $12.94^{\mathrm{ns}}$ & 291.24* \\
\hline Residue & 16 & 142.20 & 2.43 & 4843.70 & 21.30 & 41.55 & 4.54 & 69.94 \\
\hline Total & 19 & & & & & & & \\
\hline$P$ value & & 0.0254 & 0.0183 & 0.4413 & 0.5567 & 0.0197 & 0.0703 & 0.0233 \\
\hline \multirow{2}{*}{ SV } & \multirow{2}{*}{ DF } & \multicolumn{7}{|c|}{ Medium square } \\
\hline & & $\mathrm{SH} / \mathrm{SD}$ & $\mathrm{SH} / \mathrm{RL}$ & SDM/RDM & SH/SDM & RSG & RT & DQI \\
\hline Treatment & 3 & $2.15^{\mathrm{ns}}$ & $0.15^{\mathrm{ns}}$ & $1.61^{\mathrm{ns}}$ & $166.32^{\text {ns }}$ & $1216.82^{\mathrm{ns}}$ & $0.02^{\mathrm{ns}}$ & $11.67^{\mathrm{ns}}$ \\
\hline Residue & 16 & 5.62 & 0.46 & 3.36 & 130.61 & 2292.14 & 0.01 & 8.59 \\
\hline Total & 19 & & & & & & & \\
\hline$P$ value & & 0.7672 & 0.7995 & 0.7009 & 0.3171 & 0.6676 & 0.1080 & 29.11 \\
\hline
\end{tabular}

SV: source of variation; DF: Degree of freedom; * significant at the level of $5 \%$ probability $(p<0.05)$ and ns: not significant $(p>0.05)$.

On the shoot height (SH), an effect of first and second degree on the variable was observed, however, it was better adjusted to the quadratic polynomial regression model, with the maximum value obtained of $51.86 \mathrm{~cm}$ with the concentration of $46.2 \%$ of goat biofertilizer (GB). This value corresponds to an increase of $72.64 \%$ when compared to the control $(0 \%)$, which obtained an average value of $30.04 \mathrm{~cm}$ (Figure 1 ).

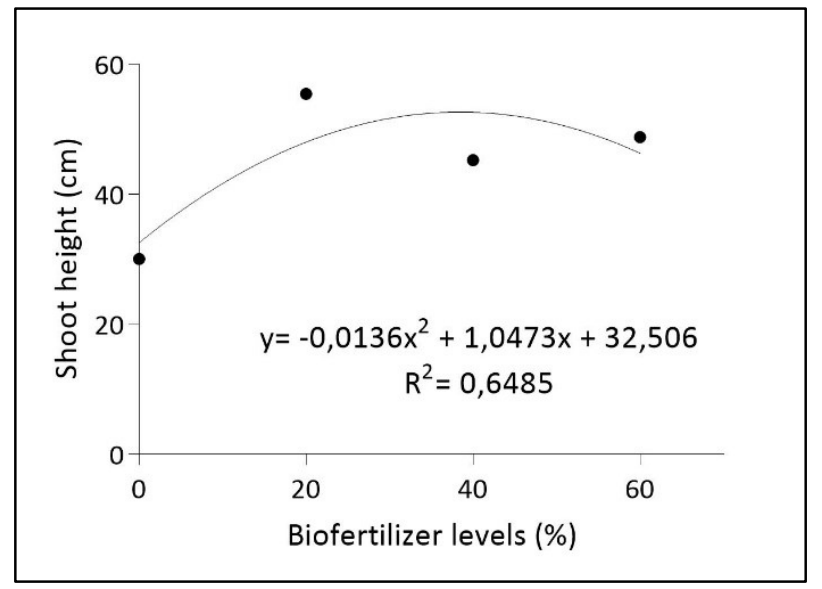

Figure 1: Shoot height $(\mathrm{cm})$ of pepper plants using a goat biofertilizer.

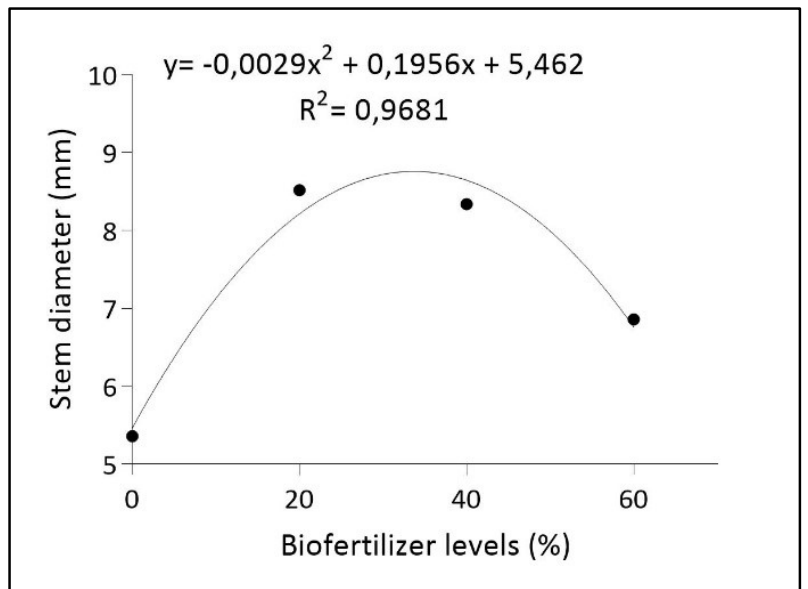

Figure 2: Stem diameter ( $\mathrm{mm}$ ) of pepper plants using goat biofertilizer.

It is noticed that there is an increasing development in $\mathrm{SH}$ as the concentration of GB increases up to 46.2\%. After this level, the PH tends to have its development inhibited, possibly due to the high concentration of compounds present in the GB that caused a toxic effect on the plant. However, Santos et al. (2020), testing the effect of GB on jambu (Acmella oleracea), claim that the compound based on goat manure provides an increase in $\mathrm{SH}$ and in the productivity of the jambu culture, the same being observed with the pepper. This result shows the potential of this compound for the initial growth of the species.

Observing the stem diameter (SD), it was found that it had a behavior similar to the SH variable, presenting an effect of both first and second degree, adjusting to the quadratic model with the best result obtained $(8.62 \mathrm{~mm})$ with the $40.46 \%$ concentration of GB. This value corresponds to an increase of $60.82 \%$ 
in the SD when compared to the value obtained in the control $(5.36 \mathrm{~cm})$ (Figure 2).

Like SH, SD also registered an inhibitory effect on its development as the concentration of GB exceeded $40.46 \%$. Souza et al. (2019), testing the effects of goat, bovine manure and soil salinity on the culture of broad beans, claim that goat manure promotes greater growth in biometrics and biomass, which may explain the increases caused in morphological parameters of the pepper by GB .

Analyzing the behavior of shoot dry mass regression curve (SDM), as a function of GB doses, revealed the concentration of $47.36 \%$ as the one responsible for the maximum aerial part dry mass production, 15.19 g. However, there was a decrease in production, in concentrations above $47.36 \%$ (Figure 3).

Quadros et al. (2010), evaluating the effect of GB on the production of dry mass in elephant grass, registered an increase in SDM with the increase in the dose of GB, when compared with treatments that were not fertilized. Results like this show that GB has a potential fertilizer in crops of economic interest, as goat excrement is rich in nutrients that aid plant development. However, based on the results shown in Figure 3 , further research on the subject should be carried out as it may cause an inhibitory effect on plant growth and development.

Santos et al. (2013) proved the efficiency of the biofertilizer of bovine origin in sorghum, where the dry mass production of sorghum cultivars, IPA 1011 and Santa Elisa were higher in the treatments with the biofertilizer. In the work developed by Costa et al. (2014), found that the goat biofertilizer had a more positive influence on the growth of BRS Gabriela castor seedlings, as it has a better chemical composition.

For the TDM variable, it was observed through the quadratic regression curve that the concentration of $48.43 \%$ of GB provided the maximum production of $18.84 \mathrm{~g}$, a behavior similar to that found in the variable SDM, which from $48.43 \%$ shows a decrease in the curve (Figure 4 ).

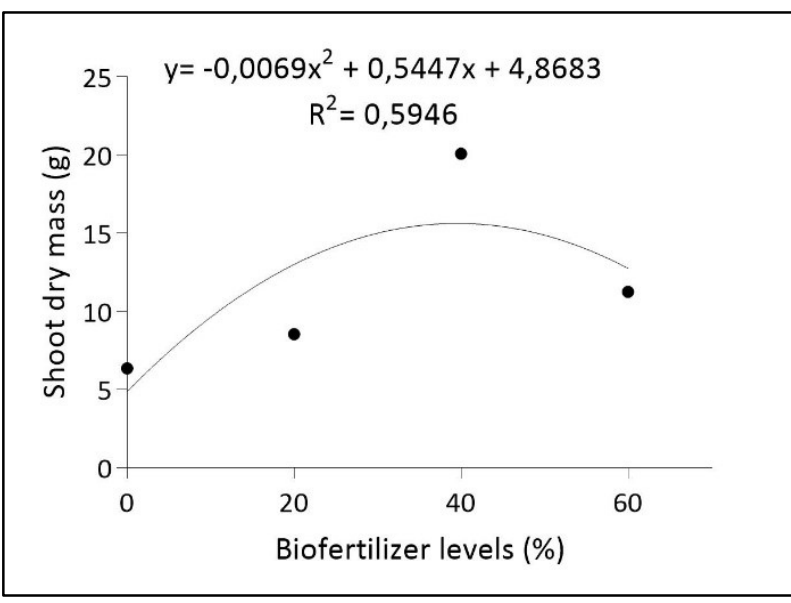

Figure 3: Shoot dry mass (g) of pepper plants using goat biofertilizer.

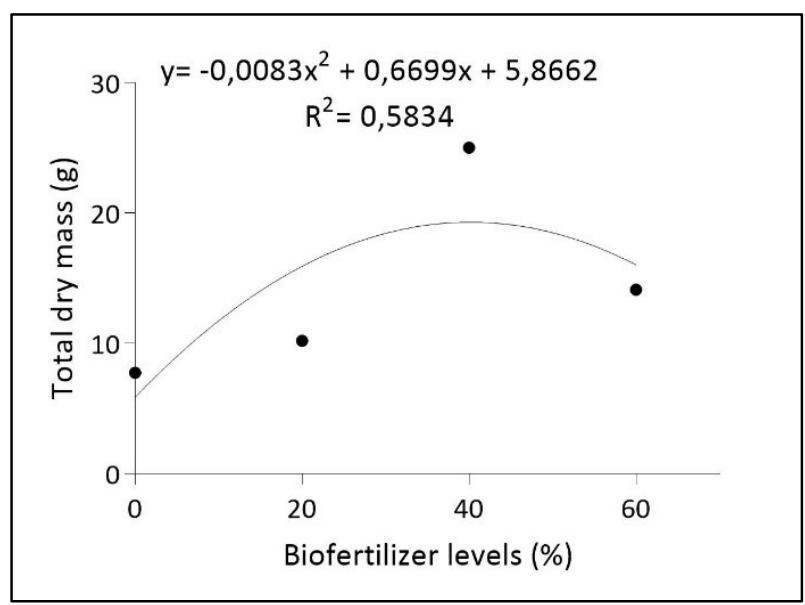

Figure 4: Total dry mass (g) of pepper plants using goat biofertilizer.

According to Gonçalves et al. (2014) the higher this value, the more rusted the seedling will be, since the seedlings must be hardened (lignified) at the time of planting, that is, with greater biomass, presenting greater resistance to adverse conditions in the field, which promotes greater survival and minimizing expenses with replanting.

Caldeira et al. (2012), in his work with Ateleia glazioviana in different proportions of biosolids, the 
total dry mass varied between 9.5 to $1.12 \mathrm{~g}$ values lower than those found in this work. Gonçalves et al. (2014) evaluating the growth of Ateleia glazioviana in substrates containing different organic materials, the highest averages for total dry mass (TDM), occurred in seedlings grown with the substrates of the treatment that contained 20,30 and $40 \%$ of $G B$.

This increase in the total dry mass content of the pepper is possibly the result of the accumulation of the concentration of organic matter in the goat biofertilizer in the treatments, as it is known the improvements that organic matter makes possible in the physical, chemical and biological properties of the soil, in addition to the benefit that provides plant nutrition (SILVA et al., 2017). However, Barros et al. (2020) found different results, where the caprine biofertilizer did not promote accumulation of dry matter in papaya seedlings, showing the need for more research on the use of this compound.

An explanation for the inhibitory effects found in the present research is due to the large amount of compounds that can harm the development of the pepper. It is known that high concentrations of manure can be harmful to plant development (LISBOA et al., 2018), because the excess of some nutrients prevents the absorption of other elements that are essential to plants, or the supply of micronutrients in large quantities, which ends up becoming toxic to the plant.

In recent years, the development of research aimed at promoting increasingly sustainable agriculture has become more common. It is possible to see research with the use of household waste (FERREIRA et al., 2020a; FERREIRA et al., 2020b), organic substrates (OLIVEIRA et al., 2019; PEREIRA et al., 2019), use of humic substances (OLIVEIRA et al., 2020), among others, which show the interest of the agricultural sector in seeking alternative technologies that do not harm the environment. The use of goat biofertilizer is a viable alternative that promotes the achievement of this objective. However, more research is needed on the effect of these compounds on plant development.

\section{CONCLUSIONS}

The use of goat biofertilizer influenced the morphological development of the pepper plant. It presented promising results that can serve as a basis for future research.

It is recommended 4 (four) applications of doses of goat biofertilizer with a concentration between $46 \%$ (460 $\left.\mathrm{ml} \mathrm{L}^{-1}\right)$ to $48 \%\left(480 \mathrm{ml} \mathrm{L}^{-1}\right)$ to obtain pepper seedlings (Capsicum frutescens L.) with good phytotechnical quality, because in this range the best results were found for most of the analyzed variables.

\section{REFERENCES}

BARROS, C. M. B.; VANOLLI, B. S.; VICENSI, M.; ÁVILA, F. W.; BOTELHO, R. V.; MÜLLER, M. M. L.. Organic substrates and foliar spray of biofertilizer on production of papaya seedlings. Research, Society and Development, v.9, n.10, p.e6359109129, 2020. DOI: http://doi.org/10.33448/rsd$\underline{\text { vi10.9129 }}$

BORGES-GÓMEZ, L.; FREGOSO, M. S.; VILLARREAL, V. C.; COHUO, E. V.; PÉREZ, G. P.. Correlación y calibración del análisis de fósforo en suelos de Yucatán, México, para el cultivo de chile habanero. Agrociência, v.42, n.1, p.21-27,
2008.

BRASIL. Ministério da Agricultura, Pecuária e Abastecimento. Instituição normativa: DAS no 17, de 21 de maio de 2007. Brasília: MAPA, 2007.

CALDEIRA, M. V. W.; PERONI, L.; GOMES, D. R.; DELARMELINA, W. M.; TRAZZI, P. A.. Diferentes proporções de biossólido na composição de substratos para a produção de mudas de timbó (Ateleia glazioveana Baill). Scientia Florestais, Piracicaba, v.40, n.93, 2012. 
CAMARGO, M. C.. A importância do uso de fertilizantes para o meio ambiente. Pesquisa \& Tecnologia, v.9, n.2, p.4, 2012.

CARDOSO, A. A. S.; SANTOS, J. Z. L.; TUCCI, C. A. F.; BARBOSA, T. M. B.. Acúmulo de nutrientes e crescimento da pimenta-de-cheiro em função de doses de calcário. Agro@mbiente, v.8, n.2, p.165-174, 2014. DOI: http://doi.org/10.18227/1982-8470ragro.v8i2.1881

COSTA, F. X.; BASÍLIO, D. O. O.; MESQUITA, E. F.; BELTRÃO, N. E. M.; ALMEIDA, A. C. V.. Produção de mudas de mamoneira BRS Gabriela utilizando lixo orgânico, esterco caprino e biofertilizante. Revista Trópica: Ciências Agrárias e Biológicas, v.8, n.1, p.48-60, 2014. DOI: http://dx.doi.org/10.0000/rtcab.v8i1.1329

CRISPIM, J. G; RÊGO, E. R.; RÊGO, M. M.; NASCIMENTO, N. F. F.. Stigma receptivity and dehiscence of pollen in an F3 generation of ornamental pepper. Horticultura Brasileira, v.32, 2018. DOI: https://doi.org/10.1590/hb.v35i4.789

DI RIENZO, J. A.; CASANOVES, F.; BALZARINI, M. G.; GONZALEZ, L.; TABLADA, M.; ROBLEDO, C. W.. InfoStat versión 2015. Córdoba: Grupo InfoStat, FCA, Universidad Nacional de Córdoba, 2015.

DICKSON, A.; LEAF, A. L.; HOSNER, J. F.. Quality appraisal of white spruce and white pine seedling stock in nurseries. Forest Chronicle, v.36, n.1, p.10-13, 1960.

FERREIRA, M. V. N.; PEREIRA, R. Y. F.; SILVA, R. O.; DOIHARA, I. P.. Resíduo de café e casca de ovo na produção de mudas de quiabo (Abelmoschus esculentus L. Moench). Global Science and Technology, v.13, n.2, p.169-185, 2020a.

FERREIRA, M. V. N.; PEREIRA, R. Y. F.; RAMOS, D. S.; SILVA, R. O.; DOIHARA, I. P.; GOMES, H. S.; SOUSA, R.; MENDES, J. C.; COSTA, E. W. A.; REIS, C. S.. Morphological indices of okra seedlings produced with coffee grounds and eggshells. International Journal of Development Research, v.10, n.08, p.39700-39704, 2020b. DOI:

https://doi.org/10.37118/ijdr.19712.08.2020

FILGUEIRA, F. A. R.. Novo manual de olericultura: Agrotecnologia moderna na produção e comercialização de hortaliças. 3 ed. Viçosa: UFV, 2008.

GONÇALVES, E. O.; PETRI, G. M.; CALDEIRA, M. V. W.; DALMASO, T. T.; SILVA, A. G.. Crescimento de mudas de Ateleia glazioviana em substratos contendo diferentes materiais orgânicos. Floresta e Ambiente, v.21, n.3, p.339348, 2014. DOI: https://doi.org/10.1590/2179-8087.029213

MEDINA-LARA, F.; MACHADO, I. E.; ARJONA, R. P.; LAU, N. R.; GUZMÁN-ANTONIO, A.; ESTEVEZ, M. M.. Influence of nitrogen and potassium fertilization on fruiting and capsaicin content in habanero pepper (Capsicum chinense Jacq.). Hort Science, v.43, p.1549-1554, 2008. DOI: https://doi.org/10.21273/HORTSCI.43.5.1549

NOGUEIRA, V. F. B.; CORREIA, M. F.; NOGUEIRA, V. S. Impacto do Plantio de Soja e do Oceano Pacífico Equatorial na Precipitação e Temperatura na Cidade de ChapadinhaMA. Revista Brasileira de Geografia Física, Recife, n.3, p.708-724, 2012. DOI: https://doi.org/10.26848/rbgf.v5.3.p708-724
OGBO, F. C.. Conversion of cassava wastes for biofertilizer production using phosphate solubilizing fungi. Bioresource Technology, v.101, n.11, p.4120-4124, 2010. DOI: https://doi.org/10.1016/i.biortech.2009.12.057

OLIVEIRA, A. P.; SILVA, O. P. R.; BANDEIRA, N. V. S.; SILVA, D. M. S.; SILVA, J. A.; PINHEIRO, S. M. G.. Rendimento de maxixe em solo arenoso em função de doses de esterco bovino e biofertilizante. Revista Brasileira de Engenharia Agrícola e Ambiental, v.18, n.11, p.1130-1135, 2014a. DOI: http://dx.doi.org/10.1590/18071929/agriambi.v18n11p1130-1135

OLIVEIRA, J. R.; GOMES, R. L. F.; ARAÚJO, A. S. F.; MARINI, F. S.; LOPES, J. B.; ARAÚJO, R. M.. Estado nutricional e produção da pimenteira com o uso de biofertilizantes líquidos. Agriambi, v.18, n.12, p.1241-1246, 2014b. DOI: https://doi.org/10.1590/1807-1929/agriambi.v18n12p1241$\underline{1246}$

OLIVEIRA, P. S. T.; CARNEIRO, C. A. M.; PEREIRA, R. Y. F.; ANDRADE, H. A. F.; SILVA-MATOS, R. R. S.. Produção de mudas de açaizeiro em substratos a base de caule decomposto de babaçu. Agrarian Academy, v.6, p.11-19, 2019. DOI:

http://doi.org/10.18677/Agrarian Academy 2019a26

OLIVEIRA, P. S. T.; SILVA, F. L. S.; CORDEIRO, K. V.; SOUSA, G. S.; NUNES, R. L. S.; PEREIRA, R. Y. F.; ALBANO-MACHADO, F. G.; OLIVEIRA, M. M. T.; SILVA-MATOS, R. R. S.. Efficacy of substrate and humic substance on cuttings production of Spondia purpurea L. Research, Society and Development, v.9, n.8, e60985006, 2020. DOI: https://doi.org/10.33448/rsd-v9i8.5006

OZA, E. F.; MONACO, P. A. V. L.; SANTOS, M. M.; ROSADO, T. L.; KRAUSE, M. R.; GARCIA, W. A.. Aproveitamento de escória de siderurgia em substratos alternativos para produção de mudas de pimenteira Dedo-de-moça. Revista Ceres, v.65, n.1, p.104-109, 2018. DOI: http://dx.doi.org/10.1590/0034737×201865010014

PASSOS, M. L. V.; ZAMBRZYCKI, G. C.; PEREIRA, R. S.. Balanço hídrico e classificação climática para uma determinada região de Chapadinha-MA. Revista Brasileira de Agricultura Irrigada, Fortaleza, v.10, n .4, p.758-766, 2016. DOI: http://doi.org/10.7127/rbai.v10n400402

PEREIRA, R. Y. F.; MORAIS, S. F.; OLIVEIRA, P. S. T.; NUNES, R. L. S.; SANTANA, M. S.; ALBANO, F. G.; SILVA-MATOS, R. R. S.. Substratos alternativos para produção de mudas de maracujazeiro em Chapadinha-MA. In: SILVA-MATOS, R. R. S.; FURTADO, M. B.; FARIAS M. F.. Tecnologia de produção em fruticultura. Ponta Grossa: Atena, 2019. p48-59. DOI: http://doi.org/10.22533/at.ed.0311909106

PEREIRA, R. Y. F.; FERREIRA, M. V. N.; CUNHA, W. P.; RAMOS, D. S.; SOUSA, F. B. F.; SOUSA, S. S. N.; BARROSO, V. B.; OLIVEIRA, P. S. T.. Postharvest losses of fruit and vegetables and their financial impacts on retail in the Municipality of Chapadinha, Maranhão. Research, Society and Development, v.9, n.8, p.e329985390, 2020. DOI: http://doi.org/10.33448/rsd-v9i8.5390

PINTO, C. M. F.; LIMA, P. C.; SALGADO, L. T.; CALIMAN, F. R. B.. Nutrição mineral e adubação para pimenta. Informe 
Agropecuário, v.27, p.50-57, 2006.

QUADROS, D. G.; OLIVER, A. P. M.; REGIS, U.; VALLADARES, R.; SOUZA, P. H. F.; FERREIRA, E. J.. Biodigestão anaeróbia de dejetos de caprinos e ovinos em reator contínuo de PVC flexível. Revista Brasileira de Engenharia Agrícola e Ambiental, v.14, n.3, p.326- 332, 2010. DOI: http://dx.doi.org/10.1590/S1415-43662010000300014

RÊGO, E. R.; RÊGO, M. M.; FINGER, F. L.. Production and breeding of chilli peppers (Capsicum spp.). Springer, New York, 2016.

RÊGO, E. R.; RÊGO, M. M.; MATOS, I. W. F.; BARBOSA, L. A.. Morphological and chemical characterization of fruits of Capsicum spp. accessions. Horticultura Brasileira, v.29, n.3, p.364-371, 2011. DOI: http://dx.doi.org/10.1590/S0102$\underline{05362011000300018}$

SANTOS, H. G.; JACOMINE, P. K. T.; ANJOS, L. H. C.; OLIVEIRA, V. A.; COELHO, M. R.; LUMBRERAS, J. F.; ALMEIDA, J. A.; CUNHA, T. J. F.; OLIVEIRA, J. B.. Sistema Brasileiro de Classificação de Solos. Brasília: Embrapa, 2018.

SANTOS, I. C. S.; PORTELA, V. O.; SAMPAIO, I. M. G.; GUSMÃO, S. A. L.. Productive response of jambu to the application of biofertilizer in coverage. Research, Society and Development, v.9, n.8, e613985918, 2020. DOI: https://doi.org/10.33448/rsd-v9i8.5918

SANTOS, J. F.; GRANGIERO, J. I. T.; SILVA, E. D.; SOUSA, J. S.. Produção de sorgo em função de cultivares e biofertilizantes bovino líquido. Revista Verde, v.8, n.3, p.156-162, 2013. DOI: https://doi.org/10.18378/rvads.v8i3.2311

SCHMITZ, J. A. K.; SOUZA, P. V. D.; KÄMPF, A. N.. Propriedades químicas e físicas de substratos de origem mineral e orgânica para o cultivo de mudas em recipientes. Ciência Rural, v.32, n.6, p.937-944, 2002. DOI:
http://dx.doi.org/10.1590/S0103-84782002000600005

SELBACH, J. F.; LEITE, J. R. S. A.. Environment in Lower Parnaíba: eyes in the world, feet in the region. São Luís: EDUFMA, 2008.

SILVA, J. A.; OLIVEIRA, A. P.; ALVES, G. S.; CAVALCANTE, L. F.; OLIVEIRA, A. N. P.; ARAÚJO, M. A. M.. Rendimento do inhame adubado com esterco bovino e biofertilizante no solo e na folha. Revista Brasileira de Engenharia Agrícola e Ambiental, v.16, n.3, p.253-257, 2012. DOI: http://dx.doi.org/10.1590/S1415-43662012000300003

SILVA, A. C.; SILVA, V. S. G.; MANTOVANELLI, B. C.; SANTOS, G. M.. Formação de mudas de alface em diferentes bandejas e substratos. Revista da Universidade Vale do Rio Verde, v.15, n.1, p.465-471, 2017. DOI: http://dx.doi.org/10.5892/ruvrd.v15i1.3011

SOUZA, M. V. P.; SOUSA, G. G.; SALES, J. R. S.; FREIRE, M. H. C.; SILVA, G. L.; VIANA, T. V. A.. Saline water and biofertilizer from bovine and goat manure in the Lima bean crop.Revista Brasileira de Ciências Agrárias, v.14, n.3, e5672, 2019. DOI: http://doi.org/10.5039/agraria.v14i3a5672

SOUSA, G. G.; VIANA, T. V. A.; BRAGA, E. S.; AZEVEDO, B. M.; MARINHO, A. B.; BORGES, F. R. M.. Fertirrigação com biofertilizante bovino: Efeitos no crescimento, trocas gasosas e na produtividade do pinhão-manso. Revista Brasileira de Ciências Agrárias, v.8, n.3, p.503-509, 2013. DOI: http://doi.org/10.5039/agraria.v8i3a2288

SOUZA, J. L.; RESENDE, P.. Manual de Horticultura orgânica. Viçosa: Aprenda Fácil, 2003.

TRANI, P. E.; TERRA, M. M.; TECCHIO, M. A.; TEIXEIRA, L. A. J.; HANASIRO, J.. Adubação Orgânica de Hortaliças e Frutíferas. Campinas: IAC, 2013.

A CBPC - Companhia Brasileira de Produção Científica (CNPJ: 11.221.422/0001-03) detém os direitos materiais desta publicação. Os direitos referem-se à publicação do trabalho em qualquer parte do mundo, incluindo os direitos às renovações, expansões e disseminações da contribuição, bem como outros direitos subsidiários. Todos os trabalhos publicados eletronicamente poderão posteriormente ser publicados em coletâneas impressas sob coordenação da Sustenere Publishing, da Companhia Brasileira de Produção Científica e seus parceiros autorizados. Os (as) autores (as) preservam os direitos autorais, mas não têm permissão para a publicação da contribuição em outro meio, impresso ou digital, em português ou em tradução. 